\title{
SOME PARAMETERS OF GROWTH IN THE COMMON INTERTIDAL BARNACLE, BALANUS BALANOIDES (L.)
}

\author{
By H. Barnes and Margaret Barnes \\ The Marine Station, Millport, Scotland
}

(Text-figs. I-6)

It is difficult to determine the weight or nitrogen content of the living tissues of an operculate barnacle without destroying it. It has been customary, therefore, in ecological work to express growth in terms of various parameters determined from repeated measurements of the shell. Moore (1934) employed shell volume calculated from the height and basal diameters; others (Costlow \& Bookhout, I953, I956; Mawatari, Hirosaki \& Kobayashi, I954a, b) have used the area of the basis. Most commonly, however, in growth-rate studies the length of the basis measured through the rostro-carinal axis has been used (Hatton, I938; Barnes \& Powell, I953). Recently, working with animals cultured in the laboratory when the cast of an individual could be obtained subsequent to ecdysis, Costlow \& Bookhout (1957) have used the size of the mouthparts as a measure of growth after first establishing their relation to body size. The space, both areal and volumetric, occupied by a sedentary animal is of primary importance in studies of its ecology and measurements of shell-size are, therefore, adequate for many purposes. For some aspects of growth and ecology it is, nevertheless, very desirable that the relation between such parameters and others, more directly connected with the living material, should be established.

\section{THE MATERIALS AND METHODS}

The specimens of Balanus balanoides (L.) were collected from near mid-tide level, individuals being selected that had had unrestricted growth and were, therefore, of the typical conical shape. Two collections were made; the first was in the autumn, just prior to the time at which fertilization takes place, and when the reproductive products were fully developed, and the second in the early winter after fertilization when the reproductive products were minimal. The shell dimensions were obtained using a travelling microscope. The body (prosoma and thorax) was then carefully separated, by cutting the attachment to the opercular valves, and weighed. Ovarian tissue when present was removed and weighed separately. After weighing, the body or ovary was 
transferred to a Kjeldahl flask, wet ashed in the usual way and the nitrogen determined as ammonia by a standard procedure for milligram quantities; the ammonia was absorbed in a saturated solution of boric acid and titrated with $\mathrm{N} / 40$ or $\mathrm{N} / 80$ hydrochloric acid. For the smallest animals pooled samples were used. Total shell weight and shell volume were determined on a separate series of individuals in which the animal's body was carefully removed without destroying the operculum. The shells were weighed dry and then carefully filled with plasticine and re-weighed; the shell volume (mantle cavity) was calculated from the increase in weight and the previously determined density of plasticine.

Wet weight of the body $(W)$, wet weight of ovary $(O)$, their total nitrogen contents $\left(N_{W}\right.$ and $\left.N_{O}\right)$, and the weight of calcareous shell $\left(W_{S}\right)$ are expressed in $\mathrm{mg}$, length of the rostro-carinal diameter $(L)$ along the basis in $\mathrm{mm}$, and volume of the mantle cavity $(V)$ is given in $\mu$ l.

\section{Body weight and total nitrogen}

\section{RESULTS}

The relation between body weight and its total nitrogen content is shown in Fig. I. It is clear that the relation is linear and that the results fall on two separate lines which represent animals collected in autumn and winter. In the former the tissues include the fully developed male reproductive organs and their products which in the latter are only poorly developed. The regression of total nitrogen on body weight is

$$
N_{W}=0.0086+0.0215 W
$$

for the autumn animals, and

$$
N_{W}=0.0530+0.0143 W
$$

for the early winter animals. For a given body weight, above about $5 \mathrm{mg}$, which represents the approximate size at which the animals reach sexual maturity, the autumn animals have a higher nitrogen content than those collected in early winter, and this is consistent with the fact that a high nitrogen content ( $3.1 \%$ wet weight) was found for the semen expressed from ripe animals.

\section{Body weight and ovarian tissue}

The female reproductive organs and their products are conspicuous in the base of the mantle cavity of animals collected in the autumn and may be easily separated from the body. Fig. 2 suggests that at smaller body weights the relation is not linear, the relative weight of female reproductive tissue falling off with decreasing body weight. When tested by the appropriate statistical technique the deviation from linearity is not, however, significant 


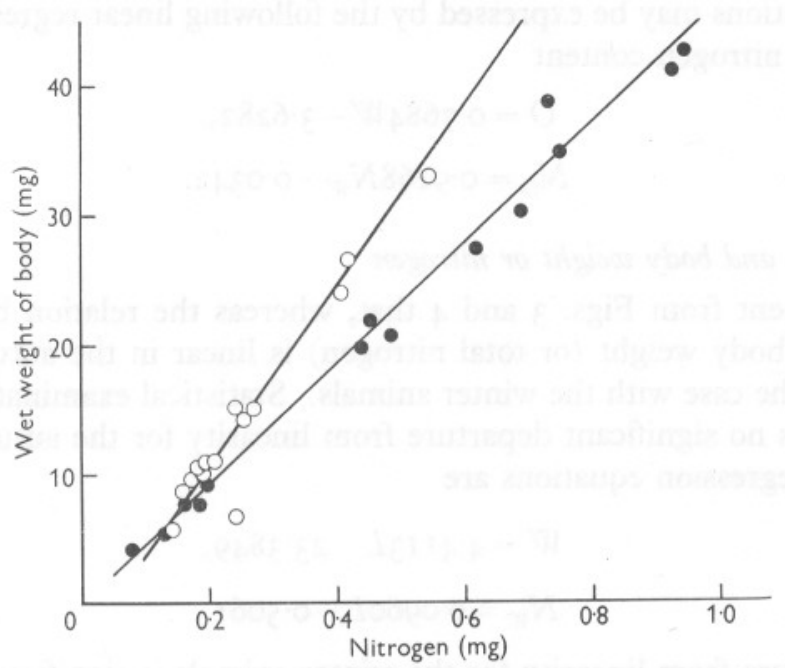

Fig. I. B. balanoides: relation between body weight and total nitrogen content; $-\bullet$, animals taken in early autumn with well-developed male organs and reproductive products; $-\mathrm{O}-$, animals taken in early winter with poorly developed male organs: regression lines drawn.

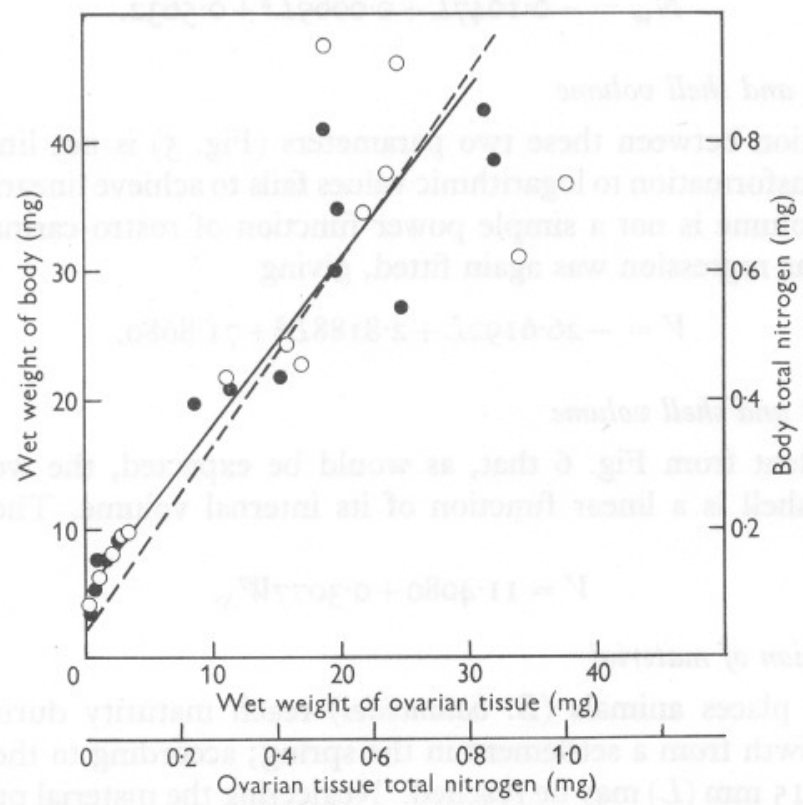

Fig. 2. B. balanoides: relation between body weight and ovarian tissue weight $(--)$ and body total nitrogen and ovarian tissue total nitrogen (-- ---$)$ : regression lines drawn. 
and the relations may be expressed by the following linear regressions for the weight and nitrogen content

and

$$
O=0.7684 W-3.6282 \text {, }
$$

$$
N_{O}=0.9168 N_{W}-0.0342 \text {. }
$$

Shell length and body weight or nitrogen

It is evident from Figs. 3 and 4 that, whereas the relation between shell length and body weight (or total nitrogen) is linear in the autumn animals, this is not the case with the winter animals. Statistical examination indicates that there is no significant departure from linearity for the autumn animals; the linear regression equations are

and

$$
\begin{aligned}
& W=4.4 \mathrm{II}_{3} L-23.3849, \\
& N_{W}=0.0960 L-0.506 \mathrm{I} .
\end{aligned}
$$

The departure from linearity for the winter animals is significant and curvilinear regression equations were, therefore, determined. They are as follows:

and

$$
\begin{aligned}
& W=-4.6938 L+0.3593 L^{2}+22.4883 \\
& N_{W}=-0.1047 L+0.0069 L^{2}+0.5632 .
\end{aligned}
$$

Shell length and shell volume

The relation between these two parameters (Fig. 5) is not linear and the fact that transformation to logarithmic values fails to achieve linearity indicates that shell volume is not a simple power function of rostro-carinal diameter. A curvilinear regression was again fitted, giving

$$
V=-26 \cdot 6 \mathrm{I} 92 L+2 \cdot 8 \mathrm{I} 88 L^{2}+7 \mathrm{I} \cdot 868 \mathrm{o} .
$$

\section{Shell weight and shell volume}

It is evident from Fig. 6 that, as would be expected, the weight of the calcareous shell is a linear function of its internal volume. The regression equation is

$$
V=\mathrm{II} \cdot 4080+0 \cdot 3077 W_{S} .
$$

\section{The acquisition of material}

In many places animals ( $B$. balanoides) reach maturity during the first season's growth from a settlement in the spring; according to the conditions a size up to $15 \mathrm{~mm}(L)$ may be reached. Neglecting the material present in the original cyprid, the organic and inorganic matter acquired by an animal of any given size between settlement and the early autumn when the reproductive organs are fully ripe may be readily estimated from the preceding regression 


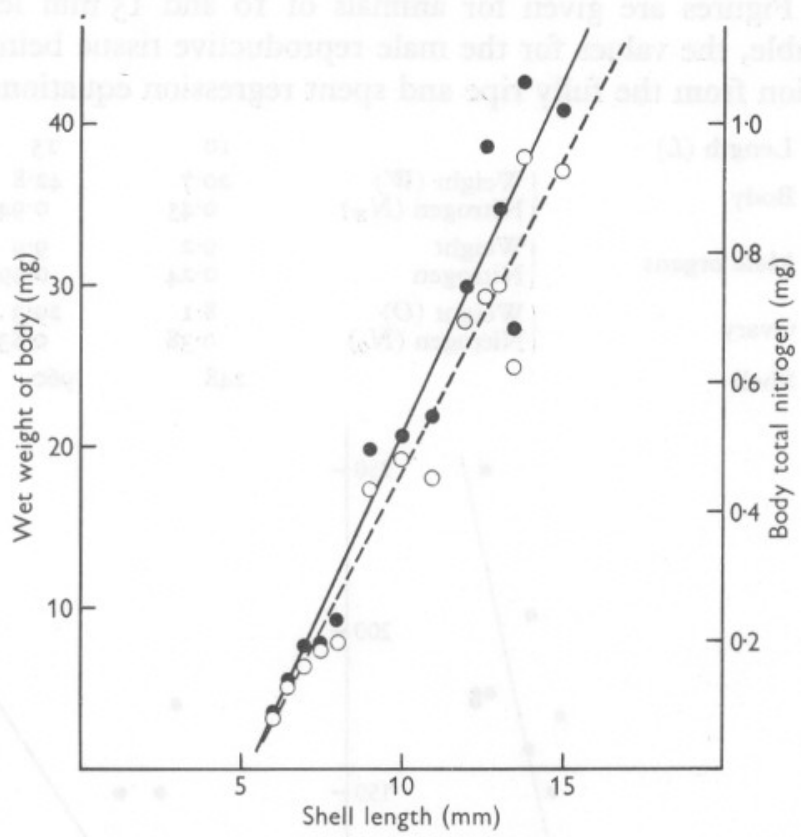

Fig. 3. B. balanoides: relation between body weight and shell length $(-\bullet)$ and body total nitrogen and shell length (-- --$)$ for animals taken in early autumn: regression lines drawn.

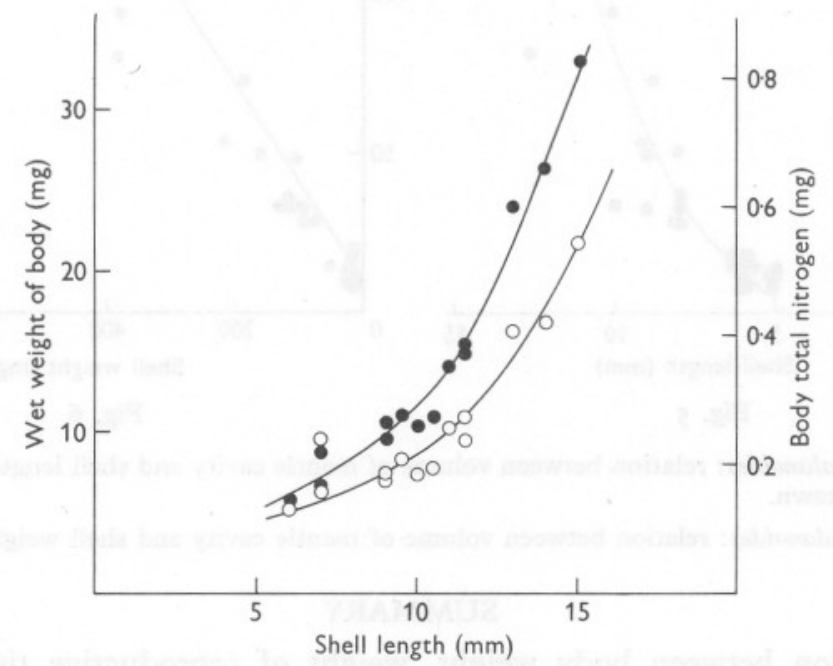

Fig. 4. B. balanoides: relation between body weight and shell length $(-\bullet)$ and body total nitrogen and shell length (- - ) for animals taken in early winter: curvilinear regressions drawn. 
equations. Figures are given for animals of 10 and $15 \mathrm{~mm}$ length in the following table, the values for the male reproductive tissue being calculated by subtraction from the fully ripe and spent regression equations:

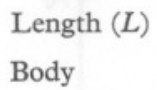

Male organs

Ovary

Shell

\{ $\begin{aligned} & \text { Weight }(W) \\ & \text { Nitrogen }\left(N_{W}\right)\end{aligned}$
$\left\{\begin{array}{l}\text { Weight } \\ \text { Nitrogen }\end{array}\right.$
$\left\{\begin{array}{l}\text { Weight }(O) \\ \text { Nitrogen }\left(N_{O}\right)\end{array}\right.$

Nitrogen $\left(N_{o}\right)$

$\begin{array}{cc}\text { I0 } & \text { I5 } \\ 20.7 & 42.8 \\ 0.45 & 0.94 \\ 9.2 & 9.9 \\ 0.24 & 0.39 \\ 8.1 & 29.3 \\ 0.38 & 0.83 \\ 248 & 960\end{array}$

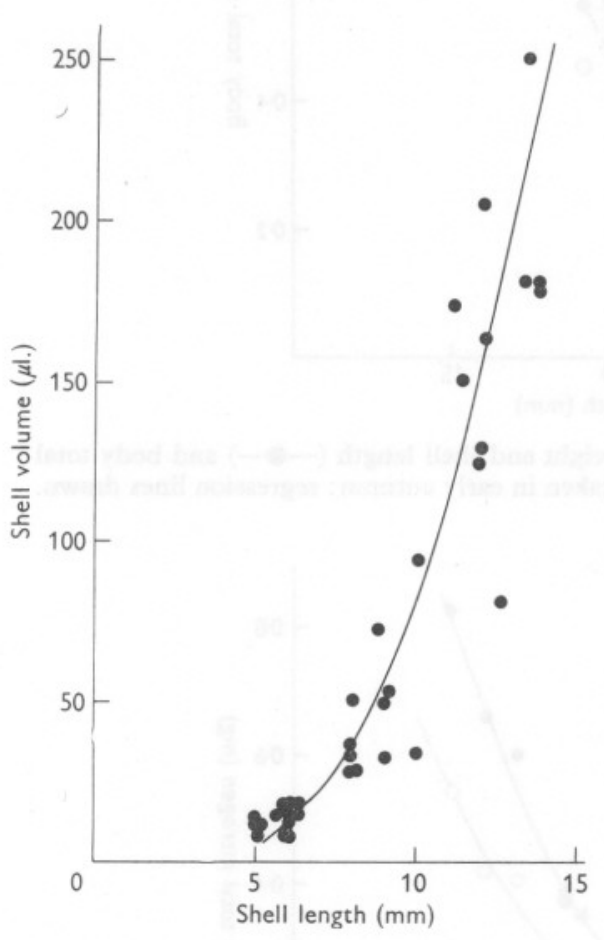

Fig. 5

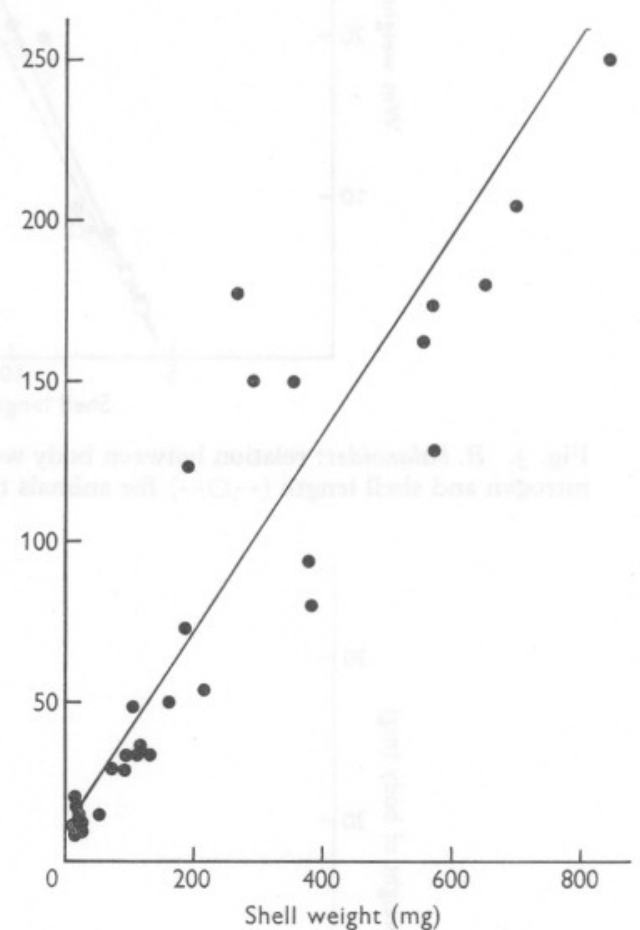

Fig. 6

Fig. 5. B. balanoides: relation between volume of mantle cavity and shell length: curvilinear regression drawn.

Fig. 6. B. balanoides: relation between volume of mantle cavity and shell weight: regression line drawn.

\section{SUMMARY}

The relation between body weight, weight of reproductive tissues, their nitrogen content, and shell length and volume, have been investigated for Balanus balanoides. The results are presented in graphs and as regression equations. 


\section{REFERENCES}

Barnes, H. \& Powell, H. T., 1953. The growth rate of Balanus balanoides (L.) and B. crenatus Brug. under varying conditions of submersion. F. mar. biol. Ass. U.K., Vol. 32, pp. 107-28.

Costlow, J. D. (Jr.) \& C. G. Bookhout, 1953. Molting and growth in Balanus improvisus. Biol. Bull., Woods Hole., Vol. 105, pp. 420-33.

- 1956. Molting and shell growth in Balanus amphitrite niveus. Biol. Bull., Woods Hole, Vol. I10, pp. I07-16.

- 1957. Body growth versus shell growth in Balanus improvisus. Biol. Bull., Woods Hole, Vol. I13, pp. 224-32.

HatToN, H., I938. Essais de bionomie explicative sur quelques espèces intercotidales d'algues et d'animaux. Ann. Inst. océanogr. Monaco, T. 17, pp. 24I-348.

Mawatari, S., Hirosaki, Y. \& Kobayashi, S., I954a. Settlement and growth of acorn barnacle, Balanus amphitrite communis Darwin. I. Misc. Rep. Res. Inst. natural Resour. Tokyo, No. 33, pp. 46-55.

- $1954 b$. Settlement and growth of acorn barnacle, Balanus amphitrite communis Darwin. II. Misc. Rep. Res. Inst. natural Resour. Tokyo, No. 34, pp. $48-57$.

Moore, H. B., 1934. The biology of Balanus balanoides. I. Growth rate and its relation to size, season and tidal level. F. mar. biol. Ass. U.K., Vol. 19, pp. $85 \mathrm{I}-68$. 